\title{
First American Cancer Patient to Receive Dicycloplatin (DCP) Chemotherapy Achieves Remission After Seven Weeks of DCP Capsules - A Case Report
}

\author{
MOHAMAD W. SALKINI ${ }^{1}$, XUQING YANG ${ }^{2}$, FAYYAZ HAIDER HASHMI ${ }^{3}$, STANLEY J. KANDZARI ${ }^{1}$, \\ THOMAS HOGAN $^{4}$, CHAD MORLEY $^{1}$, DAVID ZEKAN ${ }^{1}$, ZACHARY WERNER $^{1}$, DORIAN J. WILLIAMS ${ }^{5}$, \\ YI GUO $^{6}$, THOMAS LEWIS MATTHEW ${ }^{3}$, MICHAEL SPANGLER ${ }^{7}$ and JING JIE YU $^{8}$ \\ ${ }^{1}$ Department of Urology, School of Medicine, WVU, Morgantown, WV, U.S.A.; \\ ${ }^{2}$ College of Chemistry and Molecular Engineering, Peking University, Beijing, P.R. China; \\ ${ }^{3}$ Cardiothoracic Surgery, Suburban Hospital, Johns Hopkins Medicine, Bethesda, MD, U.S.A.; \\ ${ }^{4}$ Department of Medicine, School of Medicine, WVU, Morgantown, WV, U.S.A.; \\ ${ }^{5}$ Department of Family Medicine, School of Medicine, WVU, Morgantown, WV, U.S.A.; \\ ${ }^{6}$ University of Maryland Shore Regional Health, Easton, MD, U.S.A.; \\ ${ }^{7}$ Colorado Springs Internal Medicine (Retired), Colorado Springs, CO, U.S.A.; \\ ${ }^{8}$ Department of Biochemistry, School of Medicine, WVU Cancer Institute, \\ West Virginia University, Morgantown, WV, U.S.A.
}

\begin{abstract}
Background: The majority of bladder cancer patients experience recurrence. Cisplatin is the standard chemotherapy for muscle-invasive bladder cancer though adverse effects are often severe. Case Report: Intravenous (IV) dicycloplatin (DCP) sustained remission in an American bladder cancer patient for five years. A recurrent mass was observed in July 2021. The patient received DCP capsules for seven weeks with no significant side-effects. Complete blood count with differential and a basic metabolic panel showed no adverse effects of DCP capsules on the bone marrow, liver or renal parameters. Cystoscopy after oral DCP found no evident bladder tumors; cytology was negative for high-grade urothelial carcinoma. Conclusion: In this patient, DCP-capsules appeared to be as effective as $D C P$-IV for achieving bladder cancer remission. Both forms of DCP chemotherapy are convenient, active against several
\end{abstract}

Correspondence to: Jing Jie Yu, MD, WVU School of Medicine, P.O. Box 9300, Morgantown, WV 26506 U.S.A. Tel: +1 3046855463, Fax: +1 2026867141, e-mail: jyu@hsc.wvu.edu; yujingjie314@gmail.com

Key Words: Dicycloplatin capsules, bladder cancer, recurrence, remission, tolerable side effects.

This article is an open access article distributed under the terms an conditions of the Creative Commons Attribution (CC BY-NC-ND) 4.0 international license (https://creativecommons.org/licenses/by-nc-nd/4.0). cancer types, with decreased adverse effects compared to cisplatin. Both have been available for treating cancer patients in China. A USA clinical trial of DCP in bladder and other cancers appears warranted.

Bladder cancer (BC) cases steadily declined by about $1 \%$ per year from 2008 to 2017. Still, 17,200 deaths are expected in 2021. An estimated 83,730 adults in the United States will be diagnosed with $\mathrm{BC}$ this year. Men are about 4 times more likely than women to develop this malignancy. Among men, $\mathrm{BC}$ is the fourth most common cancer and the eighth most common cause of cancer death (1).

The main type of $\mathrm{BC}$ is non-muscle invasive tumors ( $\mathrm{T} 1$, Ta), treated with complete transurethral resection, followed by BCG (Bacillus Calmette-Guérin) intravesical immunotherapy. The vast majority of patients with high-risk $\mathrm{BC}$ endure recurrence, progression of disease, or die within ten years (27). In England, among those diagnosed with BC, $75 \%$ survive for 1 year or more, $55 \%$ for 5 years, and around $45 \%$ for 10 years after diagnosis (8-10).

Recurrence and survival depend on initial tumor stage and grade, with 5 -year recurrence rates in about $65 \%$ of patients with non-invasive or in situ tumors, and $73 \%$ of patients with slightly more advanced disease. Blute et al noted that the high recurrence rate in the first two years after diagnosis warrants an intense surveillance schedule (11). According to Cambier and colleagues, patients at high risk of recurrence and progression do poorly on current BCG maintenance schedules. Alternative treatments are needed $(12,13)$. 
Cisplatin chemotherapy is a standard protocol for muscleinvasive BC $(13,14)$. It improves survival, presumably by treating micrometastatic disease and pathologic downstaging. Cisplatin plus gemcitabine (CG) is frequently substituted for the classic MVAC combination (methotrexate, vinblastine, doxorubicin, cisplatin) to increase tolerability. In advanced or metastatic urothelial cancer, studies show noninferiority of CG versus MVAC with fewer adverse effects (15). However, adverse effects of cisplatin are often constraints to full dosage and long-term use.

Dicycloplatin (DCP), a novel platinum analog, was developed in China. It possesses an excellent safety profile. An-Tuo-Ke-Jin, the capsule formulation of DCP, was developed in 1992 for oral administration. Subsequently, DCP intravenous injection was developed for a phase I human clinical trial $(16,17)$. A phase II clinical trial using DCP+paclitaxel in non-small-cell lung cancer patients was completed in 2009 (18). In March 2012, DCP injection was approved for solid tumor chemotherapy by the State Food and Drug Administration of China (SFDA; Certificate Nos. H20120020 and H20120021).

Of note, carcinoma shares many common risk-factors or major cause-mechanisms with other chronic diseases, including type 2 diabetes and heart disease. They may relate to one another in multiple pathways. Several meta-analyses suggest that type 2 diabetes and heart disease show an increased risk of bladder, endometrial and other cancers. Inflammation can be a major cause of cancers; it may also play significant role in age-related diseases including diabetes, cardiovascular and autoimmune diseases (19-21). Khanna et al. summarized that exposure to endogenous and exogenous free radicals can damage cell DNA through oxidation and strand breaks, interfering with DNA repair. The resulting genetic mutations can lead to cancer (22). Khansari and colleagues stated that inflammation induces oxidative stress and reduces cellular antioxidant capacity. Overproduced free radicals react with cell membrane fatty acids and proteins, impairing their function permanently. Free radicals can also lead to mutation and DNA damage predisposing to cancer (23). Knowing the role of free radicals in cancer and chronic diseases would encourage antioxidant and lifestyle strategies to prevent and manage these diseases.

\section{Case Report}

The history of this case: A Caucasian American male exsmoker was diagnosed with a malignant bladder tumor (noninvasive high-grade papillary urothelial carcinoma on right lateral wall) at the age of 65 in 2016. He underwent complete transurethral resection (TURBT), declined BCG immunotherapy and then traveled to Beijing, where he received DCP chemotherapy (24). He received $300 \mathrm{mg}$ by intravenous (IV) injection weekly for eight weeks. In addition, he received encapsulated DCP (An-Tuo-Ke-Jin); four capsules (12 mg DCP) were taken three times a day for six weeks. Adverse effects included moderate back and leg aches. There was no emesis or alopecia; weekly blood counts declined but remained within normal limits (24).

After completion of DCP treatment, the patient was seen quarterly, semiannually and yearly for surveillance at WVU Ruby Hospital, Morgantown, WV, USA. Cystoscopy through January 2020 revealed no recurrence of tumor (Figure 1A and B). Computed tomography - intravenous pyelogram evaluations indicated no upper urinary tract or metastatic lesions. Cytology collected during each cystoscopy found no malignant cells (2427). Of note, during the 5 years of his remission, the patient received DCP chemotherapy once a year. That "booster" consisted of $300 \mathrm{mg}$ of DCP by IV weekly for two weeks when he traveled to China in 2017, 2018 and 2019. The boosters were given to prevent tumor recurrence.

Due to the Covid-19 pandemic, annual surveillance was paused and travel to China blocked.

In early May of 2021, the patient developed acute symptoms of coronary artery disease - angina presence unspecified: ST elevation myocardial infarction (STEMI). Of note, he has a long-term history of Type 2 diabetes and essential hypertension. On May 7, 2021, the patient underwent off-pump quadruple coronary bypass grafting by Johns Hopkins Medicine Cardiothoracic Surgeons at Suburban Hospital in Bethesda, MD, USA. The patient developed postop pleural effusion on the right side, confirmed as chylothorax, with a triglyceride content of $190 \mathrm{mg} / \mathrm{dl}$ (Pleural fluid triglyceride concentration $>$ or $=110 \mathrm{mg} / \mathrm{dl}$ is highly suggestive of a chylous effusion), on July 23, 2021. Thoracentesis was performed three times. Conservative treatment was followed with a fat-restricted, Green Mediterranean Diet (28-30). A chest $\mathrm{x}$-ray in mid-December showed only a small amount of pleural effusion. The patient exhibited no evidence of congestive heart failure before and after heart surgery.

In July of 2021, eighteen months after his last bladder surveillance, WVU urologists found a papillary mass on the right lateral bladder wall at the site of the original high grade (HG) transitional cell carcinoma (TCC) in 2016 that was considered recurrence based on its gross features. No other masses or lesions were noted within the bladder lumen (Figure 1C).

From July 4 to July 13, 2021, the patient received 3 DCP capsules 3 times daily (one capsule contains $3 \mathrm{mg}$ DCP, thus he received $27 \mathrm{mg}$ /day orally). From July 14 through August 20 of 2021, he received 4 DCP capsules 3 times daily (total 36 $\mathrm{mg} /$ day orally). During the first 5 weeks of oral DCP treatment, the patient experienced minimal side-effects. During the last 2 weeks, he reported low energy, anorexia, and decreased sensitivity to taste. Generally speaking, there were no significant side-effects. On August 13, 2021, complete blood count with differential and basic metabolic panel showed no adverse effects of DCP on bone marrow, liver or renal parameters (Table I and Table II). 
A

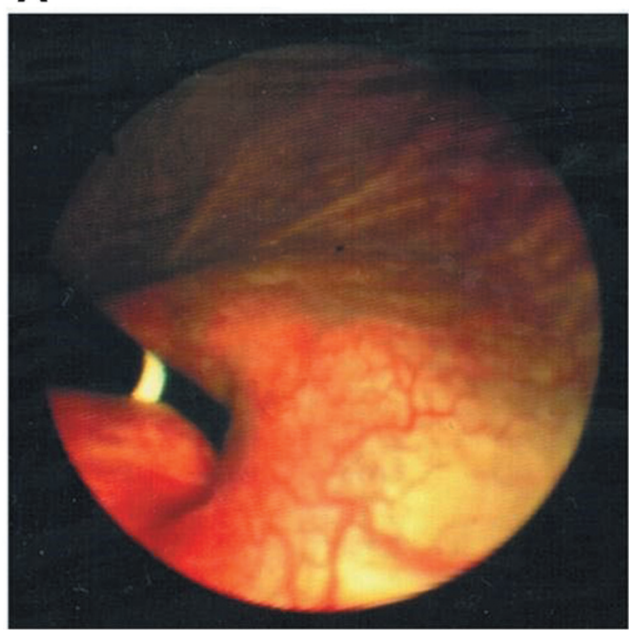

Bladder neck with flexible cystoscope on 1/14/2020

\section{B}

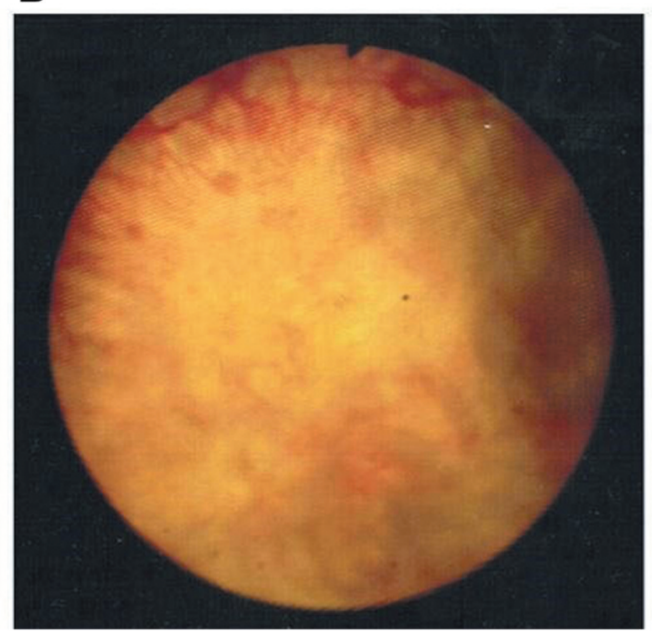

Normal-appearing former resection site on 1/14/2020

C

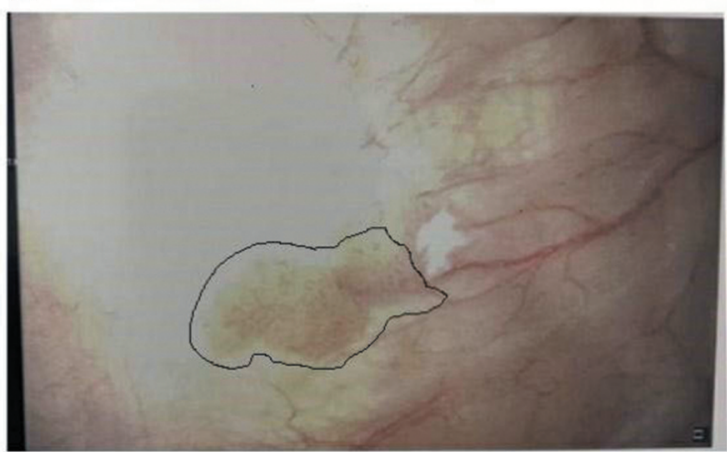

Right lateral wall papillary bladder mass

concerning for recurrence on $7 / 12 / 2021$

D

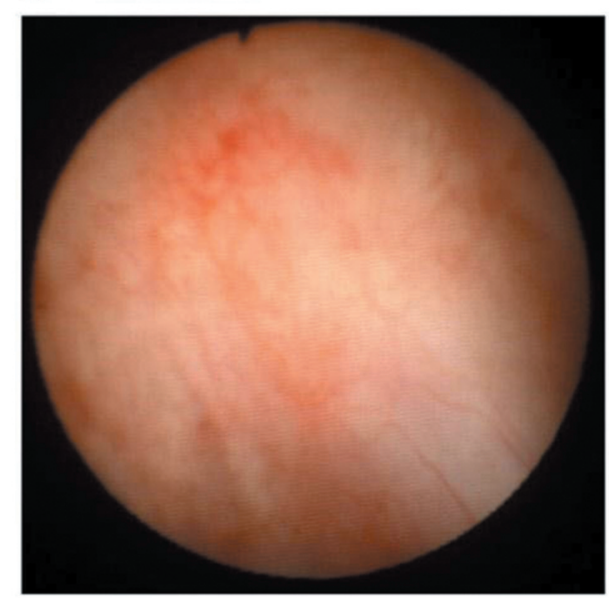

Bladder tumor resection site on $8 / 23 / 2021$

After seven weeks Dicycloplatin

capsules - no tumors observed
E

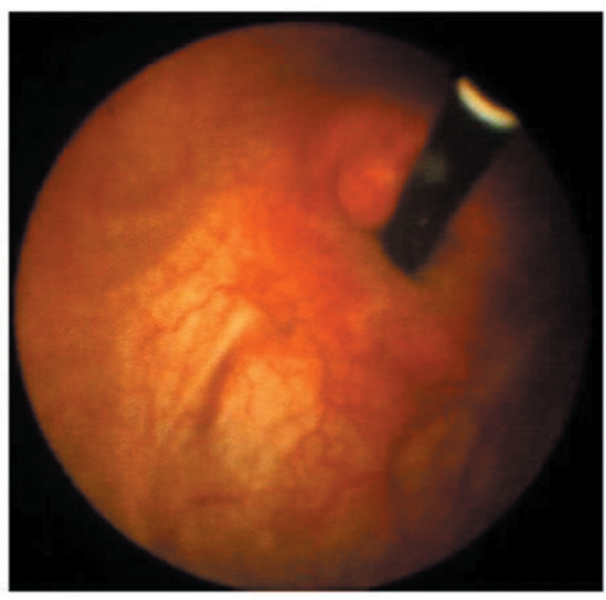

Intravesical protrusion of prostate with increased vascularity No concerning mass on $8 / 23 / 2021$

Figure 1. Cystoscopy images of the bladder resection site and recurrent tumor. Images were acquired during the cystoscopies on January 14, 2020; July 12, 2021; and August 23, 2021. A and B: The resection site appears normal; no recurrent mass was seen on January 14, 2020. C: The recurrence of papillary bladder mass observed on July 12, 2021 is shown in the circled area. D and E: Old TURBT site after a seven-week course of oral dicycloplatin appears normal on August 23, 2021, no evidence of bladder tumor. 
Table I. Complete blood count with differential on August 13, 2021.

\begin{tabular}{lcc}
\hline White blood cell & $4.8 \times 10^{3} / \mu \mathrm{l}$ & $3.7-11.0 \times 10^{3} / \mu \mathrm{l}$ \\
Red blood cell & $4.64 \times 10^{6} / \mu \mathrm{l}$ & $4.50-6.10 \times 10^{6 / \mu l}$ \\
Hemoglobin & $12.6 \mathrm{~g} / \mathrm{dl}$ & $13.4-17.5 \mathrm{~g} / \mathrm{dl}$ \\
Hematocrit & $39.6 \%$ & $38.9-52.0 \%$ \\
Mean corpuscular volume & $85.3 \mathrm{fl}$ & $78.0-100.0 \mathrm{fl}$ \\
Mean corpuscular hemoglobin & $27.2 \mathrm{pg}$ & $26.0-32.0 \mathrm{pg}$ \\
Mean corpuscular hemoglobin concentration & $31.8 \mathrm{~g} / \mathrm{dl}$ & $31.0-35.5 \mathrm{~g} / \mathrm{dl}$ \\
Red cell distribution width-coefficient of variation & $16.6 \%$ & $11.5-15.5 \%$ \\
Platelets & $244 \times 10^{3} / \mu \mathrm{l}$ & $150-400 \times 10^{3} / \mu \mathrm{l}$ \\
Mean platelet volume & $11.8 \mathrm{fL}$ & $8.7-12.5 \mathrm{fl}$ \\
Neutrophil \% & $55 \%$ & $\%$ \\
Lymphocyte $\%$ & $27 \%$ & $\%$ \\
Monocyte \% & $12 \%$ & $\%$ \\
Eosinophil \% & $5 \%$ & $\%$ \\
Basophil \% & $1 \%$ & $\mathrm{H}$ \\
Neutrophil \# & $2.66 \times 10^{3} / \mu \mathrm{l}$ & $1.50-7.70 \times 10^{3} / \mu 1$ \\
Lymphocyte \# & $1.31 \times 10^{3} / \mu \mathrm{l}$ & $1.00-4.80 \times 10^{3} / \mu \mathrm{l}$ \\
Monocyte \# & $0.58 \times 10^{3} / \mu \mathrm{l}$ & $0.20-1.10 \times 10^{3 / \mu l}$ \\
Eosinophil \# & $0.23 \times 10^{3} / \mu \mathrm{l}$ & $\leq 0.50 \times 10^{3} / \mu \mathrm{l}$ \\
Basophil \# & $<0.10 \times 10^{3} / \mu \mathrm{l}$ & $\leq 0.20 \times 10^{3} / \mu \mathrm{l}$ \\
\hline
\end{tabular}

Table II. Basic metabolic panel on August 13, 2021.

\begin{tabular}{lcc}
\hline Sodium & $138 \mathrm{mmol} / \mathrm{l}$ & $136-145 \mathrm{mmol} / 1$ \\
Potassium & $4.3 \mathrm{mmol} / \mathrm{l}$ & $3.5-5.1 \mathrm{mmol} / 1$ \\
Chloride & $103 \mathrm{mmol} / \mathrm{l}$ & $96-111 \mathrm{mmol} / \mathrm{l}$ \\
$\mathrm{CO}_{2}$ total & $27 \mathrm{mmol} / \mathrm{l}$ & $23-31 \mathrm{mmol} / 1$ \\
Anion GAP & $8 \mathrm{mmol} / 1$ & $4-13 \mathrm{mmol} / 1$ \\
Calcium & $9.4 \mathrm{mg} / \mathrm{dl}$ & $8.8-10.2 \mathrm{mg} / \mathrm{dl}$ \\
Glucose & $161 \mathrm{mg} / \mathrm{dl}$ & $65-125 \mathrm{mg} / \mathrm{dl}$ \\
Blood urea nitrogen & $14 \mathrm{mg} / \mathrm{dl}$ & $8-25 \mathrm{mg} / \mathrm{dl}$ \\
Creatinine & $0.96 \mathrm{mg} / \mathrm{dl}$ & $0.75-1.35 \mathrm{mg} / \mathrm{dl}$ \\
Blood urea nitrogen/creatinine ratio & 15 & $6-22$ \\
Estimated glomerular filtration rate & $80 \mathrm{ml} / \mathrm{min} / \mathrm{BSA}$ & $\geq 60 \mathrm{ml} / \mathrm{min} / \mathrm{BSA}$ \\
\hline
\end{tabular}

The patient was scheduled for a TURBT on August 23, 2021. He signed a consent form and was prepared for the TURBT procedure. However, due to chest pains the night before - in light of quadruple bypass earlier in the year, and requirement of general anesthesia for the TURBT - the procedure was changed to flexible cystourethroscopy with bladder barbotage under local anesthesia to evaluate the status of his bladder tumors after seven weeks of oral DCP chemotherapy. The cystoscopy on August 23, 2021 found no evidence of bladder tumors. Furthermore, cytology was negative for high-grade urothelial carcinoma (Figure 1D and E).

\section{Conclusion}

As reported in earlier articles, the adverse effects of DCP are tolerable compared to other platinum compounds, such as cisplatin and carboplatin (24-27). In vitro and in vivo studies demonstrated that DCP shares the same molecular mechanisms with cisplatin and carboplatin. Clinical studies of DCP-IV in cancer patients have shown similar efficacy and improved therapeutic ratio versus other standard IV platinum drugs $(16,27)$. In the patient reported here, oral DCP capsules appeared to be equally effective as DCP IV in suppressing his bladder cancer. If oral DCP is as efficacious as DCP IV, and both have a better therapeutic ratio than cisplatin or carboplatin, then clinical trials of DCP in bladder cancer patients in the USA appear warranted.

\section{Conflicts of Interest}

The Authors declare that they have no competing interests in relation to this study. 


\section{Authors' Contributions}

Conception and design: Jing Jie Yu, Xuqing Yang, Thomas Hogan; Patient care: Mohamad W. Salkini, Fayyaz Haider Hashmi, Stanley J Kandzari, Chad Morley, David Zekan, Zachary Werner, Dorian J. Williams, Yi Guo, Thomas Lewis Matthew, Michael Spangler, Jing Jie Yu; Data collection and assembly: Jing Jie Yu, Yi Guo; Manuscript writing: All Authors. Final approval of manuscript: All Authors.

\section{Acknowledgements}

The Authors thank Michael D. Mueller for the editorial assistance and his special contributions to this research. The Authors also thank Yaozhong $\mathrm{Wu}$ and Ying $\mathrm{Wu}$ for their professional consultations; Margaret E. Mattson, Tom Manuccia, Yin Wu, Xiaoling Tang, Ying Guo, Tao Zhang and Robert Wayne Dicus for their suggestions and encouragement.

\section{References}

1 Bladder cancer statistics. Virginia, Cancer.net, 2021. Available at: https://www.cancer.net/cancer-types/bladder-cancer/statistics [Last accessed on September 26, 2021]

2 Smith A, Milowsky M and Chen R: Chapter 83: Bladder cancer. In: Abeloff's Clinical Oncology, $5^{\text {th }}$ Ed. Niederhuber, Armitage, Doroshow, Kastan, and Tepper (eds.). Elsevier, pp. 1445-1463, 2014.

3 Alexandroff AB, Jackson AM, O'Donnell MA and James K: BCG immunotherapy of bladder cancer: 20 years on. Lancet 353(9165): 1689-1694, 1999. PMID: 10335805. DOI: 10.1016/ S0140-6736(98)07422-4

4 Sylvester RJ, van der Meijden AP, Witjes JA and Kurth K: Bacillus calmette-guerin versus chemotherapy for the intravesical treatment of patients with carcinoma in situ of the bladder: a meta-analysis of the published results of randomized clinical trials. J Urol 174(1): 86-91; discussion 91-2, 2005 PMID: 15947584. DOI: 10.1097/01.ju.0000162059.64886.1c

5 Grossman HB, Natale RB, Tangen CM, Speights VO, Vogelzang NJ, Trump DL, deVere White RW, Sarosdy MF, Wood DP Jr, Raghavan D and Crawford ED: Neoadjuvant chemotherapy plus cystectomy compared with cystectomy alone for locally advanced bladder cancer. N Engl J Med 349(9): 859-866, 2003. PMID: 12944571. DOI: 10.1056/NEJMoa022148

6 Martínez-Piñeiro JA, Jiménez León J, Martínez-Piñeiro L Jr, Fiter L, Mosteiro JA, Navarro J, García Matres MJ and Cárcamo P: Bacillus Calmette-Guerin versus doxorubicin versus thiotepa: a randomized prospective study in 202 patients with superficial bladder cancer. J Urol 143(3): 502-506, 1990. PMID: 2106041. DOI: $10.1016 / \mathrm{s} 0022-5347(17) 40002-4$

7 Sherif A, Holmberg L, Rintala E, Mestad O, Nilsson J, Nilsson S, Malmström PU and Nordic Urothelial Cancer Group: Neoadjuvant cisplatinum based combination chemotherapy in patients with invasive bladder cancer: a combined analysis of two Nordic studies. Eur Urol 45(3): 297-303, 2004. PMID: 15036674. DOI: 10.1016/j.eururo.2003.09.019

8 Survival by Stage of Bladder Cancer. London, Cancer Research UK, 2020. Available at: https://www.cancerresearchuk.org/aboutcancer/bladder-cancer/survival [Last accessed on September 26, 2021]
9 Babjuk M, Burger M, Compérat EM, Gontero P, Mostafid AH, Palou J, van Rhijn BWG, Rouprêt M, Shariat SF, Sylvester R, Zigeuner R, Capoun O, Cohen D, Escrig JLD, Hernández V, Peyronnet B, Seisen T and Soukup V: European Association of Urology guidelines on non-muscle-invasive bladder cancer (TaT1 and carcinoma in situ) - 2019 update. Eur Urol 76(5): 639-657, 2019. PMID: 31443960. DOI: 10.1016/j.eururo.2019.08.016

10 Chamie K, Litwin MS, Bassett JC, Daskivich TJ, Lai J, Hanley JM, Konety BR, Saigal CS and Urologic Diseases in America Project: Recurrence of high-risk bladder cancer: a populationbased analysis. Cancer 119(17): 3219-3227, 2013. PMID: 23737352. DOI: $10.1002 /$ cncr.28147

11 Blute ML Jr, Rushmer TJ, Shi F, Fuller BJ, Abel EJ, Jarrard DF and Downs TM: Renin-angiotensin inhibitors decrease recurrence after transurethral resection of bladder tumor in patients with nonmuscle invasive bladder cancer. J Urol 194(5): 1214-1219, 2015. PMID: 26173101. DOI: 10.1016/j.juro.2015.05.104

12 Cambier S, Sylvester RJ, Collette L, Gontero P, Brausi MA, van Andel G, Kirkels WJ, Silva FC, Oosterlinck W, Prescott S, Kirkali Z, Powell PH, de Reijke TM, Turkeri L, Collette S and Oddens J: EORTC nomograms and risk groups for predicting recurrence, progression, and disease-specific and overall survival in non-muscle-invasive stage Ta-T1 urothelial bladder cancer patients treated with 1-3 years of maintenance Bacillus Calmette-Guérin. Eur Urol 69(1): 60-69, 2016. PMID: 26210894. DOI: 10.1016/j.eururo.2015.06.045

13 Hall R: Updated results of a randomised controlled trial of neoadjuvant cisplatin $(\mathrm{C})$, methotrexate $(\mathrm{m})$ and vinblastin $(\mathrm{V})$ chemotherapy for muscle-invasive bladder cancer. Proc Am Soc Clin Oncol 21: 178A, 2002.

14 Kassouf W, Aprikian A, Black P, Kulkarni G, Izawa J, Eapen L, Fairey A, So A, North S, Rendon R, Sridhar SS, Alam T, Brimo F, Blais N, Booth C, Chin J, Chung P, Drachenberg D, Fradet Y, Jewett M, Moore R, Morash C, Shayegan B, Gotto G, Fleshner N, Saad F and Siemens DR: Recommendations for the improvement of bladder cancer quality of care in Canada: A consensus document reviewed and endorsed by Bladder Cancer Canada (BCC), Canadian Urologic Oncology Group (CUOG), and Canadian Urological Association (CUA), December 2015. Can Urol Assoc J 10(1-2): E46-E80, 2016. PMID: 26977213. DOI: $10.5489 /$ cuaj. 3583

15 von der Maase H, Hansen SW, Roberts JT, Dogliotti L, Oliver T, Moore MJ, Bodrogi I, Albers P, Knuth A, Lippert CM, Kerbrat P, Sanchez Rovira P, Wersall P, Cleall SP, Roychowdhury DF, Tomlin I, Visseren-Grul CM and Conte PF: Gemcitabine and cisplatin versus methotrexate, vinblastine, doxorubicin, and cisplatin in advanced or metastatic bladder cancer: results of a large, randomized, multinational, multicenter, phase III study. J Clin Oncol 18(17): 3068-3077, 2000. PMID: 11001674. DOI: $10.1200 / J C O .2000 .18 .17 .3068$

$16 \mathrm{Yu}$ JJ, Yang $\mathrm{X}$, Song Q, Mueller MD and Remick SC: Dicycloplatin, a novel platinum analog in chemotherapy: synthesis of chinese pre-clinical and clinical profile and emerging mechanistic studies. Anticancer Res 34(1): 455-463, 2014. PMID: 24403501.

17 Yang XQ, Yu JJ, Guo Y and Mueller MD: Dicycloplatin: A nextgeneration platinum drug for cancer chemotherapy. In: Frontiers in Clinical Drug Research - Anti-Cancer Agents. Atta-ur-Rahman (eds.). Bentham Science Publisher, pp. 3-54, 2017. 
18 Liu KJ, Guan ZZ, Liang Y, Yang XQ, Peng J, Huang H, Shao QX, Wang MZ, Zhu YZ, Wu CP, Wang SB, Xiong JP, Bai YX, Yu SY, Zhang Y, Hu XH, Feng JF, Wu SX, Jiao SC, Zhou CC, Wang J and Wu HY: A double-blind, randomized phase II study of dicycloplatin plus paclitaxel versus carboplatin plus paclitaxel as first-line therapy for patients with advanced non-small-cell lung cancers. Arch Med Sci 10(4): 717-724, 2014. PMID: 25276156. DOI: 10.5114 /aoms.2014.44862

19 Larsson SC, Orsini N, Brismar K and Wolk A: Diabetes mellitus and risk of bladder cancer: a meta-analysis. Diabetologia 49(12): 2819-2823, 2006. PMID: 17021919. DOI: 10.1007/s00125-0060468-0

20 Friberg E, Orsini N, Mantzoros CS and Wolk A: Diabetes mellitus and risk of endometrial cancer: a meta-analysis. Diabetologia 50(7): 1365-1374, 2007. PMID: 17476474. DOI: 10.1007/s00125-007-0681-5

21 Zuppinger $\mathrm{C}$ and Suter TM: Cancer therapy-associated cardiotoxicity and signaling in the myocardium. J Cardiovasc Pharmacol 56(2): 141-146, 2010. PMID: 20386457. DOI: 10.1097/FJC.0b013e3181e0f89a

22 Khanna RD, Karki K, Pande D, Negi R and Khanna RS: Inflammation, free radical damage, oxidative stress and cancer. Microinflammation 1: 109, 2014. DOI: 10.4172/2381-8727.1000109

23 Khansari N, Shakiba Y and Mahmoudi M: Chronic inflammation and oxidative stress as a major cause of age-related diseases and cancer. Recent Pat Inflamm Allergy Drug Discov 3(1): 73-80, 2009. PMID: 19149749 . DOI: $10.2174 / 187221309787158371$

24 Yu JJ, Salkini MW, Jiao S, Hogan T, Guo Y, Liang XB, Yang B, Zhang L and Gyure K: The first American cancer patient to receive dicycloplatin chemotherapy: A case report. J Cancer Res Ther 5(9): 56-60, 2017. DOI: 10.14312/2052-4994.2017-11

25 Yu JJ, Jiao S, Salkini MW, Morley C, Williams DJ, Liang XB, Yan BX, Winn AC, Guo Y, Zheng J, Hogan T, Gyure K and Petros W: Seventeen-month report for first american cancer patient to receive dicycloplatin chemotherapy. Adv Inv Pha The Medic 1: 10-13, 2018. DOI: 10.31872/2018/APTM-100102
26 Salkini MW, Morley C, Crigger C, Jiao S and Yu JJ: West Virginia resident is first American to receive dicycloplatin chemotherapy: A WVU urologic oncology case report. Clin Oncol Res 1(2): 2-3, 2018. DOI: 10.31487/j.COR.2018.02.005

$27 \mathrm{Yu}$ JJ, Hogan T, Morley C, Crigger C, Jiao S, Williams DJ, Salkini MW, Yang X, Liang X, Yan B, Cecil C, Winn AC, Zheng J, Guo YI, Jiang BH and Washington IM: Adverse effects profile of dicycloplatin (DCP) offers chemotherapeutic advantage over cisplatin and carboplatin. Anticancer Res 39(8): 4455-4462, 2019. PMID: 31366544. DOI: 10.21873/anticanres.13618

28 Schild HH, Strassburg CP, Welz A and Kalff J: Treatment options in patients with chylothorax. Dtsch Arztebl Int 110(48): 819-826, 2013. PMID: 24333368. DOI: 10.3238/arztebl.2013.0819

29 Adams SD: Chylothorax Treatment \& Management. Drugs \& Diseases, 2020. Available at: https://emedicine.medscape.com/ article/172527-treatment [Last accessed on September 26, 2021]

30 Yaskolka Meir A, Rinott E, Tsaban G, Zelicha H, Kaplan A, Rosen P, Shelef I, Youngster I, Shalev A, Blüher M, Ceglarek U, Stumvoll M, Tuohy K, Diotallevi C, Vrhovsek U, Hu F, Stampfer $\mathrm{M}$ and Shai I: Effect of green-Mediterranean diet on intrahepatic fat: the DIRECT PLUS randomised controlled trial. Gut 70(11): 2085-2095, 2021. PMID: 33461965. DOI: 10.1136/gutjnl-2020-323106
Received December 5, 2021

Revised January 14, 2022

Accepted January 17, 2022 